DOI https://doi.org/10.46845/2541-8254-2021-2(29)-13-13

УДК 637.524.2

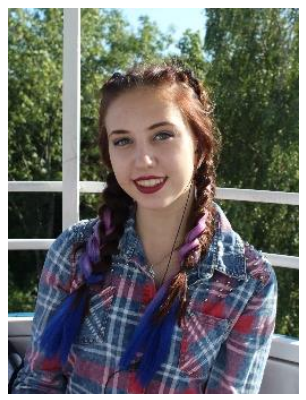

\title{
МОДЕЛИРОВАНИЕ РЕЦЕПТУРЫ ВАРЕНОЙ КОЛБАСЫ, ОБОГАЩЕННОЙ ЙОДСОДЕРЖАЩИМИ КОМПОНЕНТАМИ
}

\author{
А. В. Суняйкина, студентка 4 курса, \\ e-mail: asunyaykina54.@gmail.com \\ ФГБОУ ВО «Калининградский государственный \\ технический университет» \\ С. В. Агафонова, канд. техн. наук, \\ e-mail: svetlana.agafonova@klgtu.ru \\ ФГБОУ ВО «Калининградский государственный \\ технический университет»
}

\begin{abstract}
Разработана технология производства вареного колбасного изделия с использованием бурых водорослей рода Laminaria. Исследовано три образца водорослей рода Laminaria по органолептическим и физико-химическим показателям. Произведено математическое моделирование рецептуры в соответствии с ортогональным центральным композиционным планированием (ОЦКП) второго порядка для двух факторов. Изготовлены опытные образцы, для которых исследованы органолептические показатели качества и влагосвязывающая способность фарша. Представлена технологическая схема производства вареного колбасного изделия, обогащенного водорослями рода Laminaria.
\end{abstract}

Ключевые слова: водоросли рода Laminaria, йод, колбасное изделие вареное, полифосфат натрия, влагосвязывающая способность.

\section{ВВЕДЕНИЕ}

Заболевания щитовидной железы повсеместно распространены во всем мире. Это одна из многочисленных проблем здравоохранения, требующая решения.

Ежегодно в специализированной эндокринологической помощи нуждаются более 1,5 миллионов взрослых и 650 тысяч детей с заболеваниями щитовидной железы, основная причина которых - недостаток йода [1].

По данным Национального медицинского центра эндокринологии Минздрава России на начало 2018 г. йододефицитные заболевания с разной степенью выраженности распространены на всей территории России $[1,2]$.

По состоянию фактическое среднее потребление йода жителем России в три раза меньше установленной Всемирной организацией здравоохранения нижнепороговой нормы (150-250 мкг) и составляет всего 40-80 мкг в день [8].

В 2019 г заместитель министра здравоохранения России Олег Олегович Салагай в интервью РИА Новости объявил, что 915 тысяч детей состоят на диспансерном учете в связи с заболеваниями щитовидной железы, из этого числа $90 \%$ связано с недостаточным поступлением йода с пищей [3].

Приведенные данные свидетельствуют об актуальности разработки пищевых продуктов массового потребления, обогащенных йодсодержащими компонентами. 


\section{ОБЪЕКТЫ ИССЛЕДОВАНИЯ}

Объектами исследований явились три образца сушеной ламинарии различных производителей: ламинария слоевища АО «Красногорсклерсредства ФармаЦвет» (Россия, Московская обл.), морская капуста «Sin Young Food Co» (республика Корея), капуста, морская шинкованная ЗАО «Компания Сакура» (Россия, Сахалинская обл.).

Характеристика и внешний вид образцов ламинарии представлены в табл. 1 и на рис. 1.

Таблица 1 - Характеристика исследуемых образцов ламинарии

\begin{tabular}{|c|c|c|c|}
\hline № образца & 1 & 2 & 3 \\
\hline Наименование & $\begin{array}{c}\text { Паминария слоевища (морская } \\
\text { капуста) }\end{array}$ & $\begin{array}{c}\text { Морская капуста, } \\
\text { сушенная МИЕК }\end{array}$ & $\begin{array}{c}\text { Капуста морская } \\
\text { шинкованная сухая }\end{array}$ \\
\hline Производитель & $\begin{array}{c}\text { АО «Красногорсклерсредства } \\
\text { ФармаЦвет», Россия, } \\
\text { Московская обл., г. } \\
\text { Красногорск }\end{array}$ & $\begin{array}{c}\text { «in Young Food Со», } \\
\text { республика Корея }\end{array}$ & $\begin{array}{c}\text { ЗАО «Компания } \\
\text { Сакура», Россия, } \\
\text { Сахалинская обл., } \\
\text { Холмский р-н., с. Правда }\end{array}$ \\
\hline Вид обработки & Сушеная измельченная & сушеная цельная & сушеная шинкованная \\
\hline Масса нетто & 100 г & 50 г & 50 г \\
\hline
\end{tabular}
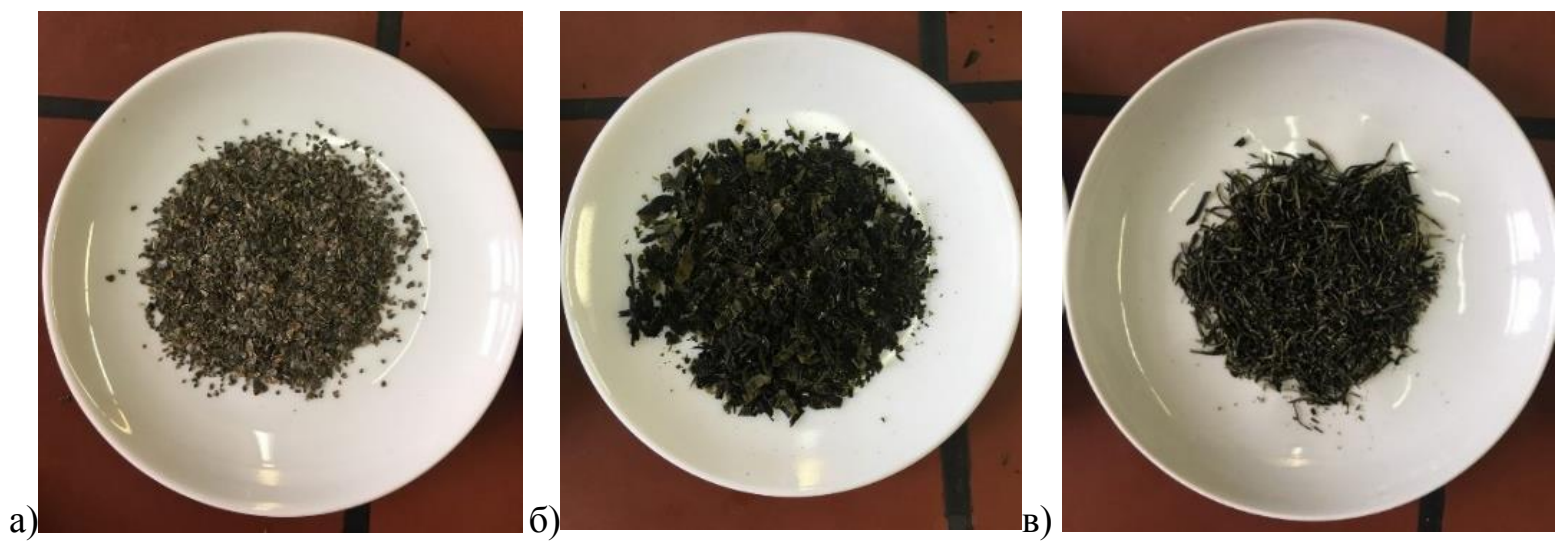

Рисунок 1 - Внешний вид исследуемых образцов ламинарии: а) слоевища ламинарии AO «Красногорсклерсредства ФармаЦвет», б) ламинарии «Sin Young Food Co», в) ламинарии ЗАО «Компания Сакура»

Также исследовали колбасные фарши с различным количеством влагосвязывающих добавок и ламинарии и готовое вареное колбасное изделие.

\section{ЦЕЛЬ И ЗАДАЧИ ИССЛЕДОВАНИЯ}

Цель исследования - оптимизация рецептуры вареной колбасы, обогащенной водорослями рода ламинария.

Задачами исследования явились:

- обоснование выбора вносимой обогащающей добавки (ламинарии);

- установление оптимальных количеств, вносимых ламинарии и полифосфата натрия в вареную колбасу с помощью метода математического моделирования;

- описание технологической схемы производства вареной колбасы, обогащенной ламинарией. 


\section{МЕТОДЫ ИССЛЕДОВАНИЯ}

Органолептическую оценку качества обогащенной вареной колбасы проводили в соответствии со специально разработанной 15-балльной шкалой.

Моделирование и оптимизация рецептуры вареной колбасы производилась в соответствии с ортогональным планированием второго порядка для двух факторов: содержания ламинарии, г и содержание полифосфата натрия, г. Их пределы варьирования приведены в табл. 2.

Таблица 2 - Изменяемые факторы (дозировки ламинарии и полифосфата натрия), их интервалы варьирования и предельные значения, г

\begin{tabular}{|c|c|c|c|c|}
\hline Факторы & \multicolumn{3}{|c|}{ Уровни } & Интервал \\
\cline { 2 - 4 } & -1 & 0 & +1 & варьирования \\
\hline Содержание полифосфата натрия, г на 100 г & 0,1 & 0,2 & 0,3 & 0,1 \\
\hline Содержание ламинарии, г на 100г & 3,2 & 4,2 & 5,2 & 1 \\
\hline
\end{tabular}

В качестве параметра оптимизации математической модели выбрана безразмерная характеристика, состоящая из двух частных откликов, значения и размерность которых приведены в табл. 3.

Таблица 3 - Частные отклики и их «идеальные» значения

\begin{tabular}{|c|c|c|}
\hline Наименование отклика & Размерность & Идеальное значение \\
\hline $\begin{array}{c}\text { Органолептическая оценка вареной колбасы, } \\
\text { обогащенной ламинарией (О) }\end{array}$ & балл & 15,0 \\
\hline $\begin{array}{c}\text { Влагосвязывающая способность обогащенного } \\
\text { колбасного фарша }\left(\mathrm{O}_{\mathrm{B}}\right)\end{array}$ & $\%$ & 100,0 \\
\hline
\end{tabular}

Данные частные отклики были выбраны для более объективного отражения качественных характеристик продукта и оптимизации его рецептуры.

В фарше и ламинарии определяли массовую долю влаги с помощью высушивания навески в сушильном шкафу до постоянной массы по ГОСТ 9793-2016, ГОСТ 333312015.

В фарше определяли влагосвязывающую способность методом Грау-Хамму в модификации Воловинской-Кельман с помощью прессования исследуемых образцов и определения количества связанной влаги.

В морской капусте определяли степень набухаемости по разнице масс сухой и поглотившей воду ламинарии.

\section{РЕЗУЛЬТАТЫ ИССЛЕДОВАНИЯ}

Проведено исследование, в результате которого из трех образцов морских водорослей рода ламинария выбирали лучший образец для обогащения вареной колбасы по ряду показателей. У каждого образца определялись органолептические показатели, влагосвязывающая способность в фарше, степень набухаемости и содержание влаги. Результаты органолептической оценки представлены в табл. 4. 
Таблица 4 - Органолептическая оценка исследуемых образцов ламинарий

\begin{tabular}{|c|c|c|c|}
\hline \multirow{2}{*}{$\begin{array}{c}\text { Наименование } \\
\text { показателя }\end{array}$} & \multicolumn{3}{|c|}{ Описание } \\
\hline & $\begin{array}{c}\text { Ламинария АО } \\
\text { «Красногорсклерсредства } \\
\text { ФармаЦвет» }\end{array}$ & $\begin{array}{l}\text { Ламинария «Sin } \\
\text { Young Food Co» }\end{array}$ & $\begin{array}{c}\text { ламинарии 3АО } \\
\text { «Компания Сакура» }\end{array}$ \\
\hline Внешний вид & $\begin{array}{c}\text { Маленькие кусочки, } \\
\text { разной формы, } \\
\text { одинаковые по размеру }\end{array}$ & $\begin{array}{c}\text { Маленькие кусочки, } \\
\text { разной формы, } \\
\text { одинаковые по } \\
\text { размеру }\end{array}$ & $\begin{array}{c}\text { Маленькие кусочки, } \\
\text { разной формы, } \\
\text { одинаковые по размеру }\end{array}$ \\
\hline Цвет & $\begin{array}{c}\text { Зелено-коричневый, } \\
\text { с белым налетом, цвет } \\
\text { тусклый }\end{array}$ & $\begin{array}{c}\text { Изумрудный, яркий, } \\
\text { без белого налета }\end{array}$ & Зеленая, без налета \\
\hline Запах & $\begin{array}{c}\text { Свойственный } \\
\text { наименованию продукта, } \\
\text { без посторонних запахов }\end{array}$ & $\begin{array}{c}\text { Свойственный } \\
\text { наименованию } \\
\text { продукта, без } \\
\text { посторонних запахов }\end{array}$ & $\begin{array}{c}\text { Свойственный } \\
\text { наименованию } \\
\text { продукта, без } \\
\text { посторонних запахов }\end{array}$ \\
\hline Вкус & $\begin{array}{c}\text { Слегка соленый, без } \\
\text { посторонних привкусов }\end{array}$ & $\begin{array}{c}\text { Не соленый, пресный, } \\
\text { без посторонних } \\
\text { привкусов }\end{array}$ & $\begin{array}{c}\text { Слабо соленый, } \\
\text { приятный, без } \\
\text { посторонних привкусов }\end{array}$ \\
\hline Консистенция & $\begin{array}{c}\text { Кусочки мягкие, хорошо } \\
\text { разжевываются }\end{array}$ & $\begin{array}{c}\text { Мягкая, при } \\
\text { разжевывании внутри } \\
\text { чувствуется } \\
\text { слизкая, не приятная, } \\
\text { скользкая структура }\end{array}$ & $\begin{array}{c}\text { Кусочки немного } \\
\text { жесткие, хорошо } \\
\text { разжевываются }\end{array}$ \\
\hline
\end{tabular}

По результатам органолептической оценки ламинария ЗАО «Компания Сакура» проявила себя как лучший образец по всем показателям.

Дальнейшие исследования заключались в определении контрольных значений влагосвязывающей способности верхнего (фарш с фосфатами) и нижнего пределов (фарш с пищевой поваренной солью), данные представлены в табл. 5 и 6.

Таблица 5 - Физико-химические показатели образцов ламинарии

\begin{tabular}{|c|c|c|}
\hline Наименование ламинарией & Набухаемость, мг/мг & Влажность, \% \\
\hline Ламинария АО «Красногорсклерсредства ФармаЦвет» & 5,24 & 92,7 \\
\hline Ламинария «Sin Young Food Co» Корея & 11,2 & 87,6 \\
\hline Ламинария ЗАО «Компания Сакура» & 16,02 & 84,7 \\
\hline
\end{tabular}

Таблица 6 - Влагосвязыывающая способность колбасных фаршей с различными добавками, \%

\begin{tabular}{|l|c|}
\hline \multicolumn{1}{|c|}{ Образец фарша } & $\mathrm{BBC}, \%$ \\
\hline С внесением поваренной соли & 32,9 \\
\hline С внесением поваренной соли и полифосфата натрия & 45,5 \\
\hline С внесением поваренной соли и ламинарии AО «Красногорсклерсредства ФармаЦвет» & 23,04 \\
\hline С внесением поваренной соли и ламинарии «Sin Young Food Со» Корея & 35,17 \\
\hline С внесением поваренной соли и ламинарии ЗАО «Компания Сакура» & 38,4 \\
\hline
\end{tabular}

По результатам проведенного исследования было выявлено, что ламинария ЗАО «Компания Сакура» по всем показателям превосходит остальные образцы. У этого образца ламинарии сильно выражена способность поглощать воду: в сравнении с показаниями других образцов ее степень набухаемости больше в 2-3 раза. Следовательно, использование данного вида ламинарии в рецептуре вареной колбасы перспективно не только с точки зрения обогащения йодом, но и в качестве функционально-технологической добавки. 
С использованием ортогонального центрального композиционного плана (ОЦКП) была построена математическая модель и определены оптимальные параметры компонентов рецептуры. Математическое моделирование отличается значительной точностью результатов [4].

План эксперимента и данные для обработки в соответствии с матрицей ОЦКП второго порядка для двух факторов приведены в табл. 7.

Таблица 7 - Матрица ортогонального планирования и план эксперимента при моделировании рецептуры вареной колбасы водорослями рода Laminaria

\begin{tabular}{|c|c|c|c|c|c|c|c|c|c|}
\hline \multirow[t]{3}{*}{ № } & \multicolumn{4}{|c|}{ План эксперимента } & \multicolumn{5}{|c|}{$\begin{array}{c}\text { Данные для математической } \\
\text { обработки }\end{array}$} \\
\hline & \multicolumn{2}{|c|}{ содержание фосфатов, г } & \multicolumn{2}{|c|}{ содержание ламинарии, г } & \multirow[b]{2}{*}{$\mathrm{x}_{0}$} & \multirow[b]{2}{*}{$\mathrm{x}_{1} \mathrm{x}_{2}$} & \multirow[b]{2}{*}{$\begin{array}{l}\mathrm{x}_{1}{ }^{-}- \\
2 / 3\end{array}$} & \multirow[b]{2}{*}{$\begin{array}{l}\mathrm{x}_{2}{ }^{2}- \\
2 / 3\end{array}$} & \multirow[b]{2}{*}{$\mathrm{y}$} \\
\hline & $\begin{array}{c}\text { по матрице } \\
\mathrm{x}_{1}\end{array}$ & $\begin{array}{c}\text { натурально } \\
\mathrm{M}_{\mathrm{H}}, \Gamma\end{array}$ & $\begin{array}{c}\text { по матрице } \\
\mathrm{x}_{2}\end{array}$ & $\begin{array}{c}\text { натурально } \\
\mathrm{M}_{\mathrm{B}}, \Gamma\end{array}$ & & & & & \\
\hline 1 & +1 & 0,3 & +1 & 5,2 & +1 & +1 & $+1 / 3$ & $+1 / 3$ & $\mathrm{y}_{1}$ \\
\hline 2 & -1 & 0,1 & +1 & 5,2 & +1 & -1 & $+1 / 3$ & $+1 / 3$ & $y_{2}$ \\
\hline 3 & +1 & 0,3 & -1 & 3,2 & +1 & -1 & $+1 / 3$ & $+1 / 3$ & $\mathrm{y}_{3}$ \\
\hline 4 & -1 & 0,1 & -1 & 3,2 & +1 & +1 & $+1 / 3$ & $+1 / 3$ & $\mathrm{y}_{4}$ \\
\hline 5 & +1 & 0,3 & 0 & 4,2 & +1 & 0 & $+1 / 3$ & $-2 / 3$ & $\mathrm{y}_{5}$ \\
\hline 6 & -1 & 0,1 & 0 & 4,2 & +1 & 0 & $+1 / 3$ & $-2 / 3$ & $\mathrm{y}_{6}$ \\
\hline 7 & 0 & 0,2 & +1 & 5,2 & +1 & 0 & $-2 / 3$ & $+1 / 3$ & $\mathrm{y}_{7}$ \\
\hline 8 & 0 & 0,2 & -1 & 3,2 & +1 & 0 & $-2 / 3$ & $+1 / 3$ & $\mathrm{y}_{8}$ \\
\hline 9 & 0 & 0,2 & 0 & 4,2 & +1 & 0 & $-2 / 3$ & $-2 / 3$ & $\mathrm{y}_{9}$ \\
\hline $\mathrm{X}_{\mathrm{ij}}$ & 0 & & 0 & & 9 & 0 & 0 & 0 & \\
\hline
\end{tabular}

Внешний вид изготовленных образцов показан на рис. 2.

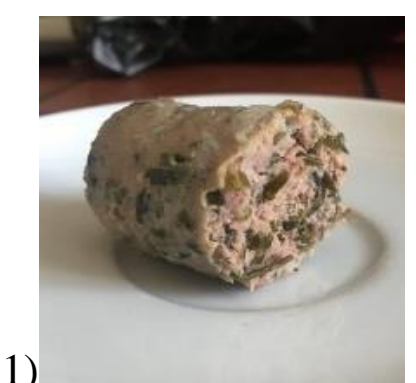

1)

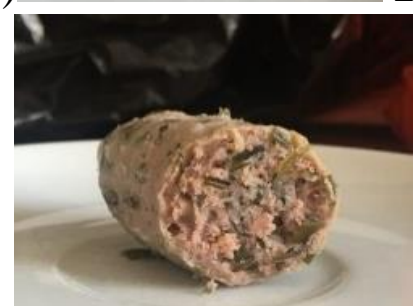

4)

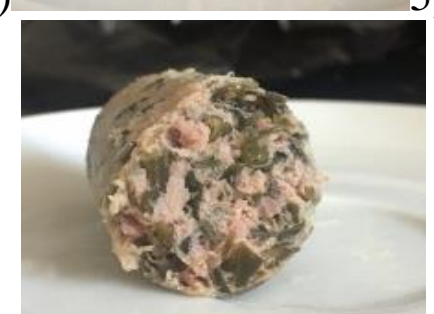

7)

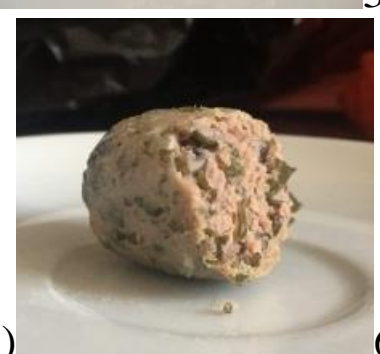

3)

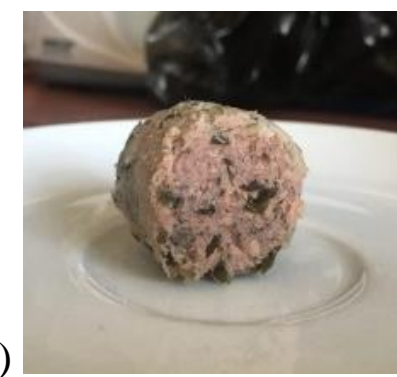

6)

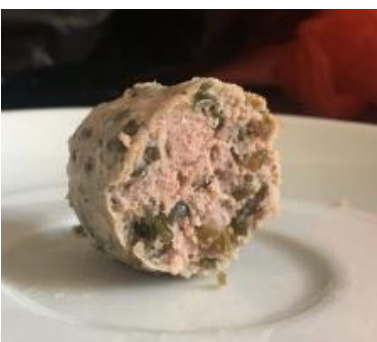

9)

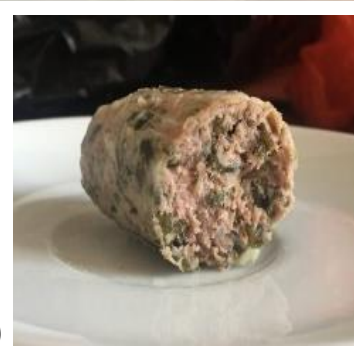

Рисунок 2 - Внешний вид вареных колбасных изделий с варьированием факторов

Произведена органолептическая оценка готовых опытных образцов в соответствии с разработанной 15-ти балльной шкалой, определялись: внешний вид, вид 
на разрезе, вкус, запах, консистенция. По результатам данных были построены профиллограммы (рис. 3).
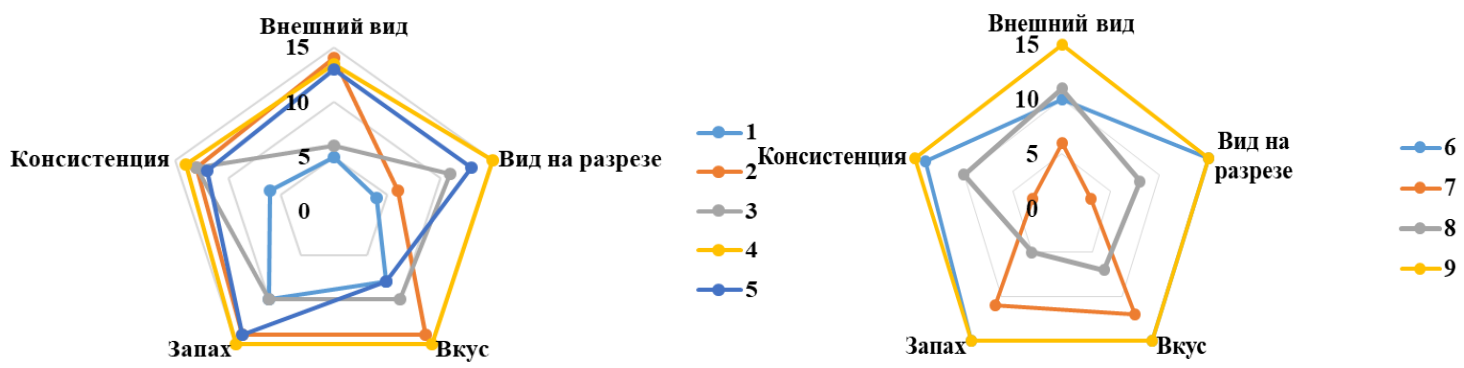

Рисунок 3 - Профилограммы органолептической оценки экспериментальных образцов вареной колбасы (слева образцы №1-5, справа образцы №6-9)

В табл. 8 представлены результаты реализации плана эксперимента.

Таблица 8 - План эксперимента и результаты его реализации

\begin{tabular}{|c|c|c|c|c|c|c|c|}
\hline \multirow[t]{2}{*}{$\begin{array}{l}\text { Номер } \\
\text { опыта }\end{array}$} & \multicolumn{2}{|c|}{$\begin{array}{c}\text { План } \\
\text { эксперимента }\end{array}$} & \multicolumn{2}{|c|}{ Частные отклики } & \multicolumn{2}{|c|}{$\begin{array}{c}\text { Частные безразмерные } \\
\text { отклики }\end{array}$} & \multirow{2}{*}{$\begin{array}{c}\text { Обобщенный } \\
\text { параметр } \\
\text { оптимизации }\end{array}$} \\
\hline & $\mathrm{M}_{\mathrm{H}}, \Gamma$ & $\mathrm{M}_{\mathrm{B}}, \Gamma$ & O, баллы & $\begin{array}{c}\mathrm{O}_{\mathrm{BBC},} \% / \\
100 \text { Г }\end{array}$ & $\mathrm{S}_{\mathrm{O}}^{2}$ & $\mathrm{~S}_{\mathrm{OH}}{ }^{2}$ & \\
\hline 1 & 0,3 & 5,2 & 6,5 & 48,4 & 0,321111 & 0,266256 & 0,5873671 \\
\hline 2 & 0,1 & 5,2 & 13,5 & 77,5 & 0,01 & 0,050625 & 0,060625 \\
\hline 3 & 0,3 & 3,2 & 10,0 & 33,64 & 0,1111111 & 0,440365 & 0,5514761 \\
\hline 4 & 0,1 & 3,2 & 14,5 & 56,5 & 0,01111 & 0,189225 & 0,1903361 \\
\hline 5 & 0,3 & 4,2 & 12,0 & 53,4 & 0,04 & 0,217156 & 0,257156 \\
\hline 6 & 0,1 & 4,2 & 14,0 & 70,0 & 0,004444 & 0,09 & 0,094444 \\
\hline 7 & 0,2 & 5,2 & 7,0 & 56,4 & 0,28444 & 0,190096 & 0,4745404 \\
\hline 8 & 0,2 & 3,2 & 9,0 & 52,3 & 0,16 & 0,227529 & 0,387529 \\
\hline 9 & 0,2 & 4,2 & 15,0 & 65,4 & 0 & 0,119163 & 0,119716 \\
\hline
\end{tabular}

После математического преобразования получили полиномиальную модель второго порядка в натуральном виде:

$$
\mathrm{y}=0,4005987+0,00424014 \mathrm{x} 1-0,19233462 \mathrm{x}_{2}+0,0414005 \mathrm{x}_{1} \mathrm{x}_{2}-0,037028 \mathrm{x}_{1}{ }^{2}+0,02182068 \mathrm{x}_{2}{ }^{2}
$$

Дифференцированием уравнений в натуральном виде были определены оптимальные значения дозировок полифосфата натрия и ламинарии, ориентированные на получение образца массой 100 г:

- содержание полифосфата натрия - 0,2 г;

- содержание ламинарии - 4,65 г.

Результатом проведенного математического моделирования стало построение пространственной трехмерной модели рецептуры вареного колбасного изделия, обогащенного водорослями рода Laminaria, представленной на рис. 4. 


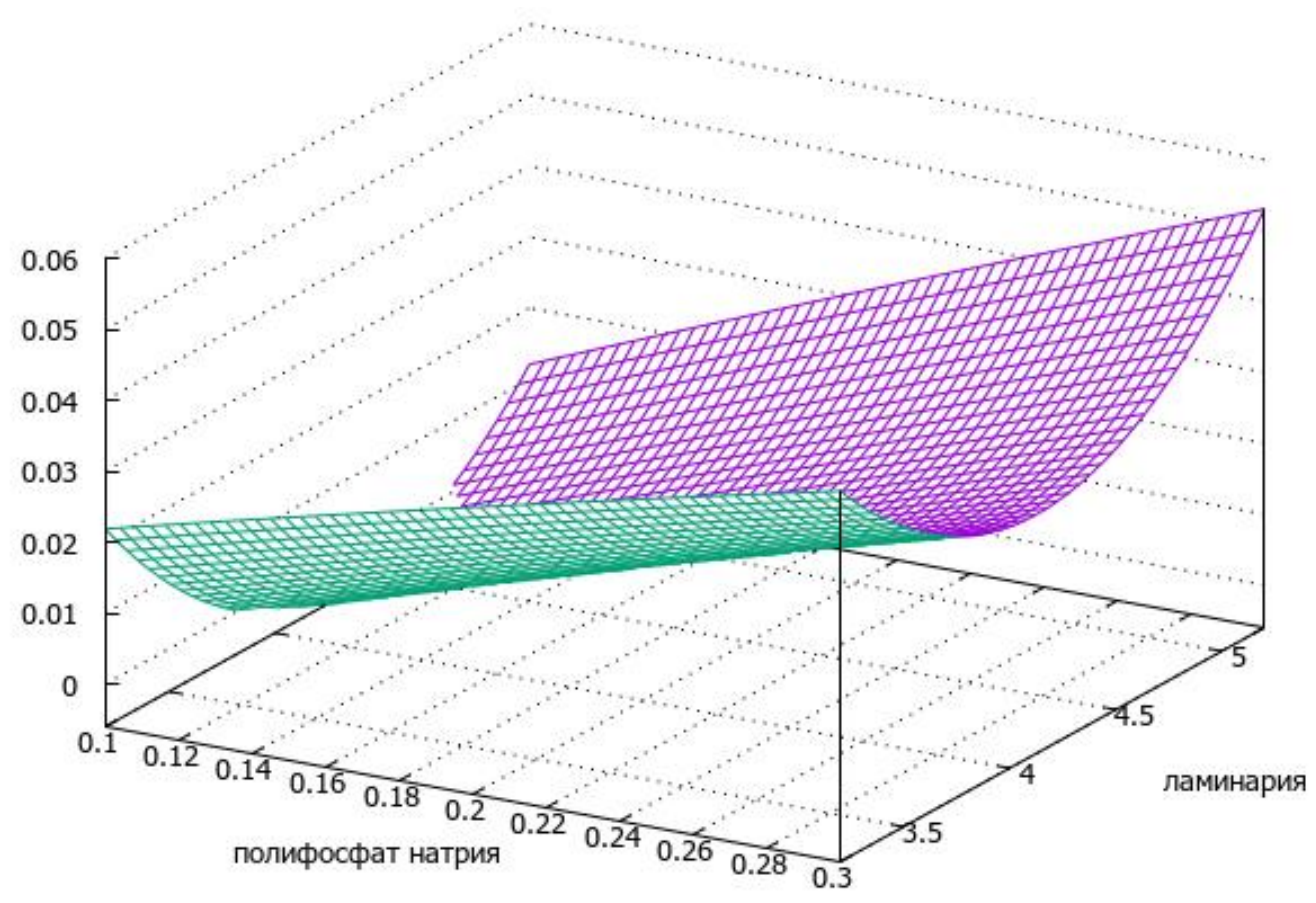

Рисунок 4 - Графическая интерпретация модели рецептуры обогащенной вареной колбасы ламинарией

По результатам проведенных исследований и анализа технических основ была разработана технологическая схема производства функционального вареного колбасного изделия с водорослями рода Laminaria, которая показана на рисунке 5, на основе технологии производства докторской вареной колбасы, которая обеспечивает не только профилактические свойства готового продукта, но и высокие вкусовые показатели [5, 6, 7]. 


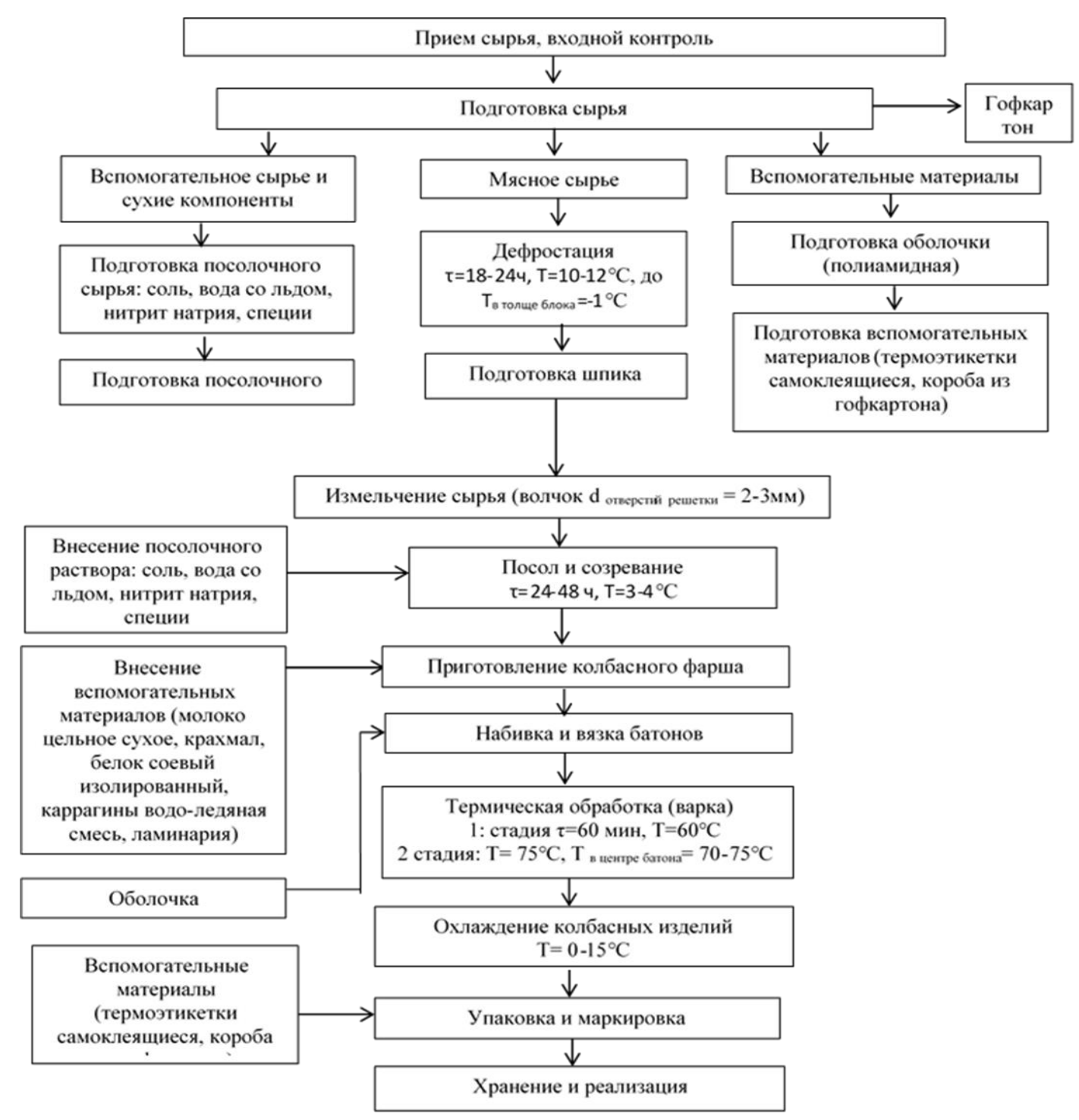

Рисунок 5 - Структурная технологическая схема процесса производства вареного колбасного изделия с водорослями рода Laminaria

\section{ЗАКЛЮЧЕНИЕ}

Водоросли рода Laminaria - богатый источник микроэлементов, в частности, йода, а также витаминов и волокон, также они являются перспективным влагосвязывающим агентом, в связи с этим их использование в производстве вареных колбасных изделий перспективно. Они повышают пищевую ценность и улучшают структурно-механические свойства фаршевых систем [8].

Были исследованы три вида образца ламинарии среди которых ламинария ЗАО «Компания сакура» проявила себя лучшим образцом по всем исследуемым показателям: органолептическая оценка, степень набухаемости. С помощью математического моделирования рецептуры установили оптимальное соотношение внесения ламинарии (4,65 г) и полифосфата натрия $(0,2$ г.) На основе технологии производства докторской вареной колбасы была разработана структурная технологическая схема процесса производства вареного колбасного изделия с водорослями рода Laminaria. 


\title{
СПИСОК ЛИТЕРАТУРЫ
}

1. Нодельман, В. Все больше россиян страдают проблемами с щитовидной железой / B. Нодельман // Известия. - 2017 [Электронный ресурс]. - URL: https://iz.ru/660787/valeriia-nodelman/vse-bolshe-rossiian-stradaiut-problemami-sshchitovidnoi-zhelezoi (дата обращения: 01.12.2020 г.).

2. Законопроект о профилактике йододефицита вынесен на общественное обсуждение. // Медвестник. - 2020 [Электронный pecypc]. - URL: https://medvestnik.ru/content/news/Zakonoproekt-o-profilaktike-iododeficita-vynesen-naobshestvennoe-obsujdenie.html (дата обращения: 01.12.2020 г.).

3. Натрускин А. Олег Салагай: йододефицита в России не будет уже через 10 лет.// РИА Новости-2019 [Электронный ресурс]. URL:https://ria.ru/20190524/1554841726.html

4. Мезенова, О. Я. Моделирование и оптимизация технологических процессов производства продуктов питания путем математического планирования эксперимента / О. Я. Мезенова. - Калининград: КГТУ, 2008. - 45 с.

5. Дагбаева, Т. Ц. Производство колбас: учебное пособие для студентов технологического факультета специальности 110305.65 очной и заочной форм обучения / Т. Ц. Дагбаева. - Изд-во ФГОУ ВПО «Бурятская государственная сельскохозяйственная академия им. В. Р. Филиппова», 2009. - 147 с.

6. Кармас, Э. Технология колбасных изделий / Э. Кармас; пер. с англ. Ф. Н. Евтеевой. - М. : Лег. и пищ. пром-сть, 2003. - 420 с.

7. Конников, А. Г. Справочник по производству колбасных изделий и мясных полуфабрикатов/ А. Г. Конников - М: Пищепромиздат, 2001г. - 292 с.

8. Суняйкина, А. В. Использование водорослей рода в технологии вареных колбас /А. В. Суняйкина, Д. В. Вихров, С. В. Агафонова // Вестник молодежной науки. - 2020 г. - № 5 (27). - С. 1-9.

\section{MODELING OF THE RECIPE OF BOILED SAUSAGE ENRICHED WITH IODINE-CONTAINING COMPONENTS}

\author{
A.V. Sunyaykina, student \\ e-mail: asunyaykina54.@gmail.com \\ Kaliningrad State Technical University \\ S.V. Agafonova, PhD in Technical Sciences ,
e-mail: svetlana.agafonova@klgtu.ru
Kaliningrad State Technical University
}

A technology for the production of cooked sausage products using brown algae of the genus Laminaria has been developed. Three samples of algae of the genus Laminaria were studied according to organoleptic and physico-chemical parameters. Mathematical modeling of the formulation was performed in accordance with the orthogonal central compositional planning (OCCP) of the second order for two factors. Experimental samples were made, for which the organoleptic quality indicators and the moisture-binding ability of minced meat were studied. The technological scheme of production of boiled sausage products enriched with algae of the genus Laminaria is presented.

Key words: algae of the genus Laminaria, iodine, boiled sausage, sodium polyphosphate, moisture-binding ability. 